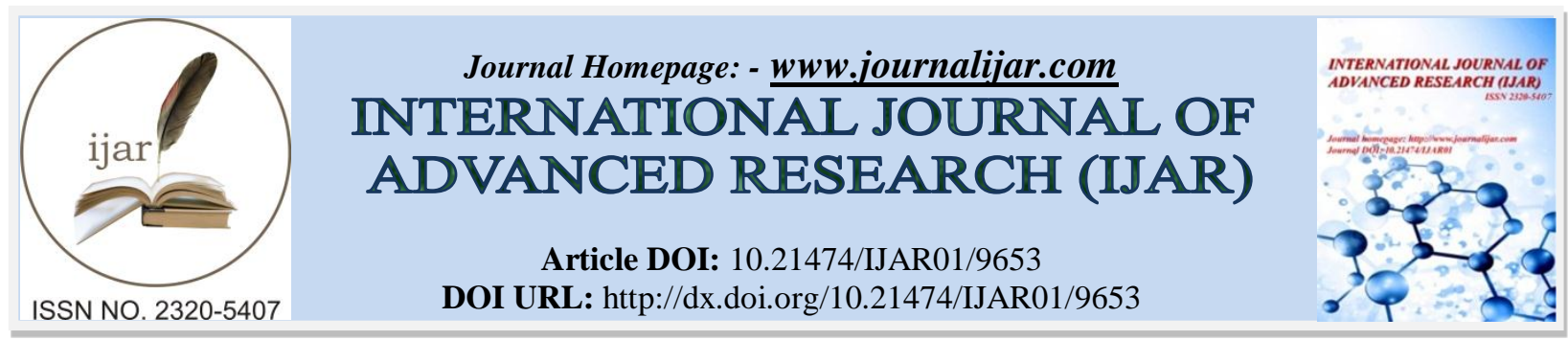

RESEARCH ARTICLE

\title{
JUSTICE REPOSITION IN THE IMPLEMENTATION OF THE DECISION OF INDUSTRIAL RELATIONSHIP DISPUTE.
}

\author{
Arpangi ${ }^{1}$, Gunarto ${ }^{2}$ and Amin Purnawan ${ }^{2}$. \\ 1. The Student of Law Doctoral Programme Unissula. \\ 2. Lecturers Of Faculty Of Law, UNISSULA, Semarang.
}

\section{Manuscript Info}

Manuscript History

Received: 04 July 2019

Final Accepted: 06 August 2019

Published: September 2019

Key words:-

Repositioning, Justice Value, Implementation of Industrial Relations Dispute Court Verdict.

\begin{abstract}
In the development of labor law, Law No. 2 of 2004 exists as a new alternative in efforts to resolve industrial relations aimed at realizing justice in the industrial world. However, the provisions in Article 58 of Law Number 2 Year 2004 have shown the opposite. This is because since the birth of Article 58 of Law Number 2 of 2004, decisions from industrial relations courts in any industrial relations dispute have resulted in uncertainty over the term of execution of the award and the absence of sanctions also for the guilty party when it fails to fulfill the execution of the existing decision. This is further complicated by the absence of legal remedies for violating the execution of existing industrial relations disputes. So that this results in violation of justice especially for workers, the violation of justice clearly also violates the mandate of the Pancasila, the fourth paragraph opening of the 1945 Constitution of the Republic of Indonesia, and Article $28 \mathrm{D}$ paragraph (1) of the Constitution of the Republic of Indonesia 1945. Therefore, this article with the sociological juridical method intends to discuss the issue of the execution of judicial decisions on industrial relations disputes that have not been fair, especially in the city of Semarang.
\end{abstract}

Copy Right, IJAR, 2019,. All rights reserved.

\section{Introduction:-}

Industrial relations are basically very important in the industrial world because industrial development is a means of creating harmony between employers and workers, so that the implementation of the business world will be able to run well as mandated by the Pancasila and the Constitution of the Indonesian state, which then leads to the achievement of economic growth and the welfare of the nation. On the development in a country's economic growth in line with population growth and the fundamental development of existing economic structures. ${ }^{1}$

Economic development in its development can affect the system of economic growth in society or often referred to as economic growth in other words economic development will be able to support the success of economic development and vice versa economic development can accelerate and facilitate the achievement of economic

\footnotetext{
${ }^{1}$ Bambang Supriyanto, Peranan Organisasi Pekerja/Organisasi Buruh Dan Organisasi Pengusaha Dalam Penciptaan Iklim Berusaha Yang Kondusif, Forum Perkembangan industri, Yogyakarta, 2009, hal. 2
} 
development in society. Development and economic growth in the community itself is influenced by factors in the form of Natural Resources, Human Resources, and Expertise and Entrepreneurship. ${ }^{2}$

Natural Resource Factors are closely related to raw materials in a production process that consists of natural wealth in the form of soil fertility, favorable climate or weather, forest products, mining products and sea products. While Human Resources, namely labor which is seen both in terms of quality and quantity, and the Expertise and Entrepreneurship in question is the ability of each Human Resources to be able to increase the economic value of goods through the process of production, distribution, and trade. ${ }^{3}$ From the explanation of the important factors in conducting the above business, it can be concluded that another factor which is also important is the effort to create a conducive industrial development.

The development of a conducive industry basically requires the synchronization of three layers, namely the layers of employers, workers, and government. These layers are also called aspects of Human Resources incorporated in the industrial development system. With synchronization in the field of Human Resources in the industrial development system is intended so that investment can develop properly, this is because investment will develop if the industrial world in the country can run safely for investors both from outside and within the country, so that this is achieved hence the need for a conducive industrial development, so that investment will develop and economic growth is achieved. So it is clear that conducive industrial relations are needed in every country, not least in the industrial world in Indonesia. But in fact the workers are always subject to injustice in industrial relations in this country.

One of these things can be observed in the provisions of Article 58 of Law Number 2 of 2004 concerning Settlement of Industrial Relations Disputes which states that in the proceedings at the Industrial Relations Court, parties who are litigants are not charged, including an execution fee whose claim value is below Rp. . 150,000,000 (one hundred fifty million rupiah). Given this, the cost is charged to the country c.q. Industrial Relations Court respectively.

Because if the value of the lawsuit is less than Rp. 150,000,000 (one hundred and fifty million rupiah) the cost is borne by the state, this will hamper the implementation of the execution. As we know the budget from the state to each Industrial Relations Court is very limited, while there are so many lawsuits, resulting in decisions that already have legal force must still wait their turn to be executed if the losing party (Defendant) does not want to carry out the decision was voluntary. In fact, the decision could only be executed after years of waiting, resulting in the nominal value received by the Plaintiff (Labor) is no longer in balance with the time the lawsuit was filed. In fact, this situation was used by the Defendants to postpone the execution of the execution, because they assumed that what was received later had economic value far decreased when compared to the time of filing a lawsuit. With this situation, it can influence the mindset of workers who seek justice, that is, they will accept what the Defendant has to offer when compared to those who have struggled to find justice through the Industrial Relations Court.

This situation basically has resulted in issues of legal protection and legal justice for workers. This clearly violates the equality before the law as mandated in Article 28D paragraph (1) of the 1945 Constitution of the Republic of Indonesia. Therefore, it is necessary to further discuss the issue of "Repositioning Justice in the Implementation of Industrial Relations Dispute Court Judgment".

\section{Research Question}

The issues that will be discussed in this paper are related to the implementation of Article 58 of Law Number 2 Year 2004 which is not yet just.

\section{Research Methodologies:-}

The method used in this writing is sociological juridical, where the discussion method used sees the law as not only limited to the perspective of the legality of the law, but also looks at the sociological aspects that develop in society, especially in the city of Semarang.

\footnotetext{
${ }^{2}$ Ibid, hal. 2

${ }^{3}$ Loc, cit
} 


\section{Discussion:- \\ Execution of Current Industrial Relations Court Decisions}

Although the issuance of Law Number 2 of 2004 which began to be effectively implemented on January 14, 2006 was considered a new alternative in resolving industrial relations disputes, in reality the Law Number 2 of 2004 still seemed to prioritize the interests of employers over the interests of workers. This can be seen in Article 58 of Law No. 2 of 2004 which states that in the proceedings at the Industrial Relations Court, parties who are litigants are not charged, including the execution costs whose claim value is below Rp. 150,000,000 (one hundred fifty million rupiah). Given this, the cost is charged to the country c.q. Industrial Relations Court respectively.

Because if the value of the lawsuit is less than Rp. 150,000,000 (one hundred and fifty million rupiah) the cost is borne by the state, this will hamper the implementation of the execution. As we know the budget from the state to each Industrial Relations Court is very limited, while there are so many lawsuits, resulting in decisions that already have legal force must still wait their turn to be executed if the losing party (Defendant) does not want to carry out the decision was voluntary. In fact, the decision could only be executed after years of waiting, resulting in the nominal value received by the Plaintiff (Labor) is no longer in balance with the time the lawsuit was filed. In fact, this situation was used by the Defendants to postpone the execution of the execution, because they assumed that what was received later had economic value far decreased when compared to the time of filing a lawsuit. With this situation, it can influence the mindset of workers who seek justice, that is, they will accept what the Defendant has to offer when compared to those who have struggled to find justice through the Industrial Relations Court.

It is clear that the current implementation of industrial relations judicial decisions with the provisions in Article 58 of Law Number 2 of 2004 has not been able to effectively realize justice for workers. This can be seen in the data on industrial relations case decisions in the Yogyakarta District Court and in the Industrial Relations Dispute Court in Semarang. At the Yogyakarta District Court, it was seen that there were 32 (thirty two) Industrial Relations Disputes Cases that entered the court, but only 11 (eleven) cases were decided, and of the eleventh only 5 (five) cases could be executed, according to Zulfahmi Anwar as clerk of the District Court, Corruption Crime, and Yogyakarta Industrial Relations Dispute Class IA that it is because most of the cases are related to workers' severance which the employer feels unable to pay with the standard of service as stipulated in Law Number 132003 . $^{4}$

Furthermore, in the District Court, Corruption Crime, and Semarang Industrial Relations Dispute Class IA, it is also clear that in 2018 there were 36 (thirty six) cases that went to court, but only 25 (twenty five) cases were capable of being executed. . R. Joko Purnomo as Registrar of District Courts, Corruption Crimes, and Semarang Industrial Relations Disputes Class IA said that most cases related to termination of employment and severance issues, but the majority of case executions were carried out between workers and employers outside the court by cooperating with the clerks as a mediator in reaching an agreement related to severance pay. ${ }^{5}$ Furthermore Wuryanto as a member of the Semarang National Workers' Union stated that labor organizations basically intend to fight for justice issues in resolving industrial relations disputes in Semarang either through demonstrations on May Day or through litigation in the judiciary, but according to him it cannot run effectively due to attitudes and Workers' culture in Semarang which only prioritizes pragmatic reasons in the form of maintaining a comfort zone in terms of maintaining their jobs, this is shown by the minimal number of workers or laborers participating in May Day demonstrations in Semarang, besides workers in Semarang also when litigating with employers always accepting decisions that benefit employers only because they receive a sum of money from entrepreneurs which is not in accordance with the severance amount in Law Number 13 of 2003, as well as the government and law enforcement partisanship to entrepreneurs a, this shows that there are no strict sanctions for entrepreneurs who are reluctant to carry out industrial relations case decisions in Semarang City. ${ }^{6}$

\footnotetext{
${ }^{4}$ Zulfahmi Anwar, Jumlah Eksekusi Putusan Peradilan Hubungan Industrial Di Pengadilan Negeri, Tindak Pidana Korupsi, Dan Perselisihan Hubungan Industrial Yogyakarta Kelas I.A, Wawancara Pribadi Dengan Ketua Panitera Pengadilan Negeri, Tindak Pidana Korupsi, Dan Perselisihan Hubungan Industrial Yogyakarta Kelas I.A, Dilakukan Pada 11 April 2019.

${ }^{5}$ R. Joko Purnomo, Jumlah Eksekusi Putusan Peradilan Hubungan Industrial Di Pengadilan Negeri, Tindak Pidana Korupsi, Dan Perselisihan Hubungan Industrial Semarang Kelas I.A, Wawancara Pribadi Dengan Ketua Panitera Pengadilan Negeri, Tindak Pidana Korupsi, Dan Perselisihan Hubungan Industrial Semarang Kelas I.A, Dilakukan Pada 25 April 2019.

${ }^{6}$ Wuryanto, Peran Organisasi Buruh Dalam Memperjuangkan Pekerja Pada Perselisihan Hubungan Industrial Di Kota Semarang, Wawancara Pribadi Dengan Anggota Serikat Pekerja Nasional Semarang Pada 14 April 2019.
} 
Based on the various explanations above, it is clear that the implementation of judicial decisions related to industrial relations disputes that have legal force still have not effectively brought about justice for workers or laborers. That is because there are provisions in Article 58 of Law No. 2 of 2004 concerning Settlement of Industrial Relations Disputes, wherein in this article the execution cost of the decision was charged to the government, which basically the government also could not carry out the execution of the defendant due to lack of budget. This results in workers being unable to obtain their rights even though employers have been decided to carry out court decisions that have permanent legal force. So it can clearly be concluded that the implementation of the execution of the industrial relations dispute court decision according to Article 58 of Law Number 2 of 2004 is not effective in realizing justice for workers or laborers in an industrial relations dispute.

\section{The Fairness of Justice in the Implementation of the Industrial Relations Court}

John Rawls meant that justice was the chief virtue of the existence of social institutions. But the good of the whole society cannot overthrow or impede the sense of justice of any who have acquired a sense of justice. Especially the weak people seeking justice. ${ }^{7}$ Furthermore, John Rawls basically looked at community justice more on aspects of the distribution of justice in society. Justice is translated as fairness where the principle is developed from the utilitarian principle. The theory was adopted from the principle of maxim, which is the process of maximizing a minimum in a society carried out by every individual who is in the initial position where there is no bargaining on the role and status of a community member. This principle tries to answer as far as possible about the maximization of a minimum that is closely related to the benefits of the lower classes of society that are weak. ${ }^{8}$

Based on the views of Rawls it can be concluded that Rawls views justice not based on one's socioeconomic status but rather on efforts to distribute happiness and equality to every member of society in a community life. Related to this, the issue of execution of judicial decisions on industrial relations disputes should also pay attention to the solution to the execution of a more just execution for workers or laborers, so that the rights and welfare of workers or laborers are not sacrificed by the interests of big capital entrepreneurs. So to realize this, the state needs to play an active role in the supervision, implementation, and evaluation of each judicial decision on industrial relations disputes by making the value of justice and the interests of marginal workers the main foothold. This is in accordance with the objectives of the rule of law in general. The concept of the rule of law put forward by Friedrich Julius Stahl is still well-known or still very influential, which concept is the duty of the state not only as a night watchman, but to develop more widely and actively intervene in the economic, social, and cultural fields. This concept is known as Welvaarstaat by four main elements, namely: ${ }^{9}$

1. Recognition and protection of basic human rights;

2. Nagara is based on the Trias Politica theory (separation of powers);

3. Government is organized based on the rule of law or law (wetmating bestuur)

4. There is a state administrative court tasked with handling cases of unlawful acts by the government.

Furthermore A.V Dicey states that the rule of law is a country that has the rule of law. This concept emphasizes the three main benchmarks or elements of the rule of law, namely:

1. The rule of law (supremacy of law);

2. Equality before the law (equality before the law);

The constitution is based on individual rights (the constitution based on individual rights). ${ }^{10}$

In its development, the concept of the rule of law according to Aristotle was a state that stood on the law that guarantees the justice of its citizens. So here justice is the goal to be achieved by the state in organizing the country, because justice is a prerequisite for achieving happiness in life for its citizens. To achieve this justice it is necessary to inculcate every citizen about mutual respect to every citizen, this is necessary in order to create peace and prosperity. In Indonesia, the term rule of law is often interpreted as rechtstaats or the rule of law. the use of the term is also contained in the explanation of the 1945 Constitution. The concept of the rule of law in Indonesia is then applied to the concept of the state objectives outlined in the fourth paragraph of the Preamble of the 1945

\footnotetext{
${ }^{7}$ Pan Muhammad Fais, Teori Keadilan John Rawls, Jurnal Konstitusi, 2009, hal 135.

8 John Rawls, Teori Keadilan, Pustaka Pelajar,Yogyakarta, 2011, diterjemahkan oleh Uzair Fauzan dan Heru Prasetyo, hlm.12-40.

9 Bambang Sutuyoso dkk, Aspek - aspek Perkembangan Kekuasaan Kehakiman di Indonesia, UII Press, Yogyakarta, 2005, hal 7.

${ }^{10}$ H. Juhaya S. Praja, Teori Hukum dan Aplikasinya, CV Pustaka Setia, Bandung, 2011 hal 135.
} 
Constitution and redefined in Article 28A through Article 28I of the 1945 Constitution of the Republic of Indonesia, which eventually gave birth to the concept of justice in Law No. 13 of 2003 and Law No. 2 of 2004. So it is clear that the political policy of resolving national industrial relations must return to the mandate of the Pancasila and the Constitution of the Indonesian state.

\section{Conclusion:-}

Based on the various explanations above, it is clear that the existence of Article 58 of Law Number 2 Year 2004 causes each industrial court dispute decision does not provide certainty about the implementation of the decision either in terms of the time limit for fulfilling the execution of the existing decision or in terms of guarantees for the implementation of the decision that there is a result of the absence of sanctions if an industrial ruling is breached. In addition, this has become even more complicated due to the absence of legal remedies from violations of the execution of existing industrial relations judicial decisions. So that the political policy of resolving national industrial relations must return to the mandate of the Pancasila and the Constitution of the Indonesian state.

\section{References:-}

1. Anwar, Zulfahmi, Jumlah Eksekusi Putusan Peradilan Hubungan Industrial Di Pengadilan Negeri, Tindak Pidana Korupsi, Dan Perselisihan Hubungan Industrial Yogyakarta Kelas I.A, Wawancara Pribadi Dengan Ketua Panitera Pengadilan Negeri, Tindak Pidana Korupsi, Dan Perselisihan Hubungan Industrial Yogyakarta Kelas I.A, Dilakukan Pada 11 April 2019.

2. Fais, Pan Muhammad, 2009, Teori Keadilan John Rawls, Jurnal Konstitusi.

3. Praja, H. Juhaya S., 2011, Teori Hukum dan Aplikasinya, CV Pustaka Setia, Bandung.

4. Purnomo, R. Joko, Jumlah Eksekusi Putusan Peradilan Hubungan Industrial Di Pengadilan Negeri, Tindak Pidana Korupsi, Dan Perselisihan Hubungan Industrial Semarang Kelas I.A, Wawancara Pribadi Dengan Ketua Panitera Pengadilan Negeri, Tindak Pidana Korupsi, Dan Perselisihan Hubungan Industrial Semarang Kelas I.A, Dilakukan Pada 25 April 2019.

5. Rawls, John, 2011, Teori Keadilan, Pustaka Pelajar, Yogyakarta.

6. Supriyanto, Bambang, 2009, Peranan Organisasi Pekerja/Organisasi Buruh Dan Organisasi Pengusaha Dalam Penciptaan Iklim Berusaha Yang Kondusif, Forum Perkembangan industri, Yogyakarta.

7. Sutuyoso, Bambang, 2005, Aspek - aspek Perkembangan Kekuasaan Kehakiman di Indonesia, UII Press, Yogyakarta.

8. Wuryanto, Peran Organisasi Buruh Dalam Memperjuangkan Pekerja Pada Perselisihan Hubungan Industrial Di Kota Semarang, Wawancara Pribadi Dengan Anggota Serikat Pekerja Nasional Semarang Pada 14 April 2019. 